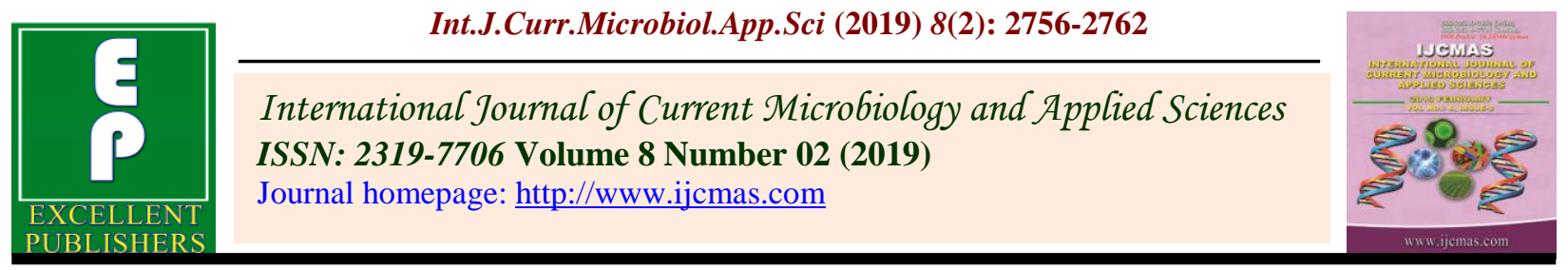

Original Research Article

https://doi.org/10.20546/ijcmas.2019.802.323

\title{
Foliar Response of Chemicals on yield and yield Attributing Characters of Rice (Oryza sativa L.) under Rain Fed Condition
}

\author{
Vikas Yadav", Mayank Pratap, A.H. Khan, R.K. Yadav and Rajneesh \\ Department of Crop Physiology, Narendra Deva University of Agriculture and Technology, \\ (Kumarganj), Faizabad-224 229 (Uttar Pradesh) India \\ *Corresponding author
}

\begin{abstract}
A B S T R A C T
\end{abstract}
The present investigation entitled "Foliar Response of Chemicals on Yield and Yield Attributing Characters of rice (Oryza sativa L.) Under Rain fed Condition" was conducted

Keywords

Rice, Rain fed,

Chemicals and yield during the Kharif season in 2016 at the Student Instructional Farm of Narendra Deva University of Agriculture and Technology, Kumarganj, Faizabad-224 229 (U.P.). Experiment was conducted in randomized block design with three replications and nine treatments on rice variety (Sahbhagidhan) under rainfed condition. Chemicals viz., foliar spray of 0.5 and $1.0 \% \mathrm{KCl}, 1.0$ and $2.0 \% \mathrm{MgSO}_{4}, 0.3$ and $0.6 \%$ Boric acid and 0.25 and $0.5 \%$ Salicylic acid at two growth stages(15 DAT and milky stage) along with untreated control (distilled water spray). Yield and yield attributing characters viz., Number of panicle bearing tiller plant ${ }^{-1}$, Number of grains panicle ${ }^{-1}$, Number of sterile grains panicle ${ }^{-1}$, Grain yield $\left(\mathrm{kg} \mathrm{ha}^{-1}\right)$, Straw yield $\left(\mathrm{kg} \mathrm{ha}^{-1}\right)$ and Test weight $(\mathrm{g})$ were improved by different chemical concentrations. On the basis of results obtained foliar application of various chemicals enhanced yield as compare to control under rain fed condition. The effects of $1.0 \% \mathrm{MgSO}_{4}$ were more pronounced fallowed by salicylic acid 0.25 and $0.5 \%$ as well as $1 \% \mathrm{KCl}$ over other treatments.

\section{Introduction}

Rice (Oryza sativa L.) as one of most important cereals worldwide is considered as the major food of more than 2 billion of peoples across the world (Akhgary, 2004). The rice is one of economically important crops in the world (Bajaj and Mohanty, 2005; Harkamal et al., 2007) which is cultivated in 114 countries (FAO, 2004).

Rice is staple food of a millions of people in the world particularly in developing countries.
About 90 per cent of rice grown in the world is produced and consumed in Asian countries (Patel et al., 2016). India rank first in respect of area (44.50 million ha) second in production (102.75 million tonnes), but the productivity of rice is very low $\left(2.20 \mathrm{t} \mathrm{ha}^{-1}\right)$ (Verma et al., 2015).

Rice has the evolutionary particularity of being semi-aquatic. The conventional system for irrigating rice is to flood, which provides water and nutrient supply under anaerobic conditions and uses large amounts of water. 
However, about half of the rice area in the world does not have sufficient water to maintain flooded conditions, and yield is therefore reduced, to some extent, by drought. Even intermittent water stress at critical stages may result in considerable yield reduction and crop failure (Bernier et al., 2008). Indeed, drought is a major limitation for rice production in rain fed ecosystems. It is not simply the lack of water that lowers yield potential, but also the timing and duration of drought stress related to phenological processes.

In addition to these environmental problems, a challenge for modern sustainable rice production is to decrease the amount of water used in rice production while maintaining or increasing the rice yield. However, rice itself has relatively few adaptations to water-limited conditions and is extremely sensitive to drought stress (Kamoshitaet al., 2008).

Foliar spraying of microelements is very beneficial to absorb nutrients (Torun et al., 2001; Parinaz et al., 2012). Several studies showed that foliar application of micronutrients on wheat crop has positive effects on crop yield parameters (Nadim et al., 2012; Masoudet al., 2012). The function of macronutrients and micronutrients is vital in crop nutrition for improved yield and quality (Saeed et al., 2012).

In field experiments conducted in Egypt, it was found that decreases in grain yield resulting from restricted irrigation could be greatly eliminated by increasing potassium (K) supply (Abd El-Hadi et al., 1997). In view of these results, it can be concluded that improvement in $\mathrm{K}$ nutritional status of plants seems to be of great importance for sustaining high yields under rain fed conditions. Possible mechanisms helpful in minimizing detrimental effects of drought by improving water use efficiency in crop plants with $\mathrm{K}$ nutrition were described by Waraich et al., (2011). Under water-deficit conditions, $\mathrm{K}$ nutrition increases crop tolerance to water stress by utilizing the soil moisture more efficiently than in K-deficient plants.

Magnesium increases the root growth and root surface area which helps to increase uptake of water and nutrients by root and transport of sucrose from leaves to roots. Magnesium improves $\mathrm{CHO}$ translocation by increasing phloem export and reduces ROS generation and photo-oxidative damage to chloroplast under drought conditions.

Boron (B) is an essential nutrient for normal growth of higher plants and its availability in soil and irrigation water is an important determinant of agricultural production (Saleem et al., 2011). Boron is responsible for better pollination, seed setting and grain formation in different rice varieties (Aslam et al., 2002; Rehman et al., 2012), making it more important during the reproductive stage as compare to the vegetative stage of the crop. Boron deficiency causes different effects on very diverse processes in vascular plants such as root elongation, in dole acetic acid oxidase activity, sugar translocation, carbohydrate metabolism, nucleic acid synthesis, and pollen tube growth (Goldbach and Wimmer, 2007; Saleem et al., 2011). Seed and grain production are reduced with low boron supply still in the absence of any observable indication of deficiency symptoms and so the requirement of $\mathrm{B}$ for reproductive increase appears to be more for reproductive development than for vegetative growth (Nalini et al., 2013).

Salicylic acid (SA), a phenolic compound, is associated with stress tolerance in plants. Previous studies report that SA can induce tolerance against high and low temperatures, drought, salinity, ultraviolet light, heavy metal toxicity, diseases and pathogens (Hayat 
and Ahmad, 2007; Horváth et al., 2007; Hussain et al., 2008). Moreover, there is evidence that exogenous application of SA can alter antioxidant capacity in plants (Rao et al., 1997), thereby providing protection against oxidative damage (Larkindale and Huang 2004), there by inducing stress tolerance.

\section{Materials and Methods}

The field experiments were carried out at main campus of Narendra Deva University of Agriculture and Technology, Kumarganj, Faizabad (U.P), India on Raibareilly road at distance of $42 \mathrm{~km}$ away from the Faizabad district head quarter. The Geographically the situation of Faizabad district lies between a latitude of $24.47^{\circ}$ and $26.56^{\circ}$ North and longitude of $18.12^{\circ}$ and $83.90^{\circ}$ east, on altitude of 113 meter about mean sea level in the Gangatic plain zone of eastern Uttar Pradesh. The experimental site was typical rainfed having sandy loam soil with $\mathrm{pH} 7.8$, electrical conductivity $0.60 \mathrm{dS} / \mathrm{m}$, organic carbon $0.56 \%$, available nitrogen $126.4 \mathrm{~kg} / \mathrm{ha}$, available phosphorous $18 \mathrm{~kg} / \mathrm{ha}$, and available potassium $210 \mathrm{~kg} / \mathrm{ha}$. The total rainfall was $652.3 \mathrm{~mm}$ during crop growth periods (June to October) in 2016. The experiments were laid out in a randomized block design with three replications. Nursery was raised from normal soil and transplanted after twenty one days old seedlings with two seedlings per hill and spacing was kept $20 \times 15 \mathrm{~cm}$ in plot size $3 \times 4 \mathrm{~m}^{2}$ in three replications. Nitrogen, Phosphorus and Potash were applied in transplanted field at the rate of 120:60:60 kg $\mathrm{ha}^{-1}$ in the form of urea, single super phosphate and murate of potash, respectively. Foliar applications of $\mathrm{KCl}(0.5$ and $1.0 \%)$, $\mathrm{MgSO}_{4}$ (1.0 and 2.0\%), Boric acid (0.3 and $0.6 \%)$ and Salicylic acid (0.25 and $0.5 \%)$ were applied at vegetative and milky stage. Observations on yield and yield attributes viz.,
Number of panicle bearing tillers plant ${ }^{-1}$, Number of grains panicle ${ }^{-1}$, Number of fertile grains panicle ${ }^{-1}$, Number of sterile grains panicle $^{-1}$, Test weight (g), Straw yield $\left(\mathrm{kg} \mathrm{ha}^{-1}\right)$ and Grain yield $\left(\mathrm{kg} \mathrm{ha}^{-1}\right)$ were taken at the time of harvesting.

\section{Results and Discussion}

\section{Yield and Yield attributing characters}

Yield is the culmination of several comprehensive phases which starts at germination and end at harvest, encompassing through shoot growth, leaf development, photosynthesis, flowering, pollination and seed set. Better vegetative growth of a crop is largely responsible for higher seed yield because number of photosynthesizing sites i.e., number of tillers is affected by initial growth stages.

All the treatments influenced number of panicle bearing tillers, total number of grains panicle $^{-1}$ and number of sterile grains panicle $^{-1}$ over untreated control (Table 1). Foliar spraying of $1 \% \mathrm{MgSO}_{4}, 2 \% \mathrm{MgSO}_{4}$, $0.3 \%$ Boric acid and $0.5 \%$ Salicylic acid significantly increased number of panicle bearing tillers plant ${ }^{-1}$, while the effect of rest of the treatments were statistically at par with untreated control.

Most of the treatments except $0.5 \% \mathrm{KCl}$ significantly increased number of total grains panicle $^{-1}$ as compared to untreated control. Highest number of grains per panicle was noted in case of $0.5 \%$ and $0.25 \%$ Salicylic acid fallowed by $2 \% \mathrm{MgSO}_{4}$ and $0.6 \%$ Boric acid.

All the treatments significantly reduced the number of sterile grains panicle ${ }^{-1}$ and minimum sterile grains panicle ${ }^{-1}$ was recorded with 0.6 and $0.3 \%$ Boric acid fallowed by $0.25 \%$ and $0.5 \%$ Salicylic acid. 
Table.1 Effect of foliar application of different chemicals on yield attributes of rice at harvest stage

\begin{tabular}{|c|c|c|c|}
\hline Treatment & $\begin{array}{c}\text { No. of panicle } \\
\text { bearing tillers } \\
\text { plant }^{-1}\end{array}$ & $\begin{array}{c}\text { No. of } \\
\text { grains } \\
\text { panicle }^{-1}\end{array}$ & $\begin{array}{l}\text { No. of sterile grains } \\
\text { panicle }^{-1}\end{array}$ \\
\hline$T_{1}-$ Control & 8.67 & 145.30 & 14.30 \\
\hline $\mathrm{T}_{2}-0.5 \% \mathrm{KCl}$ & 8.73 & 147.60 & 12.00 \\
\hline $\mathrm{T}_{3}-1.0 \% \mathrm{KCl}$ & 8.73 & 151.60 & 11.70 \\
\hline $\mathrm{T}_{4}-1.0 \% \mathrm{MgSO}_{4}$ & 9.70 & 152.60 & 11.30 \\
\hline $\mathrm{T}_{5}-2.0 \% \mathrm{MgSO}_{4}$ & 9.50 & 153.70 & 10.30 \\
\hline$T_{6}-0.3 \%$ Boricacid & 9.40 & 151.00 & 9.30 \\
\hline $\mathrm{T}_{7}-0.6 \%$ Boricacid & 8.27 & 153.30 & 9.00 \\
\hline $\mathrm{T}_{8}-0.25 \%$ Salicylic acid & 8.47 & 154.00 & 9.30 \\
\hline$T_{9}-0.5 \%$ Salicylic acid & 9.60 & 154.30 & 9.70 \\
\hline SEm \pm & 0.23 & 1.12 & 0.47 \\
\hline CD at $5 \%$ & 0.67 & 3.29 & 1.34 \\
\hline
\end{tabular}

Table.2 Effect of foliar application of different chemicals on test weight and yield of rice

\begin{tabular}{|c|c|c|c|}
\hline Treatment & $\begin{array}{l}1000 \text { grains weight } \\
\text { (g) }\end{array}$ & Grain yield $\left(\mathrm{Kg} \mathrm{ha}^{-1}\right)$ & $\begin{array}{c}\text { Straw yield } \\
\left(\mathrm{Kg} \mathrm{ha}^{-1}\right)\end{array}$ \\
\hline $\mathbf{T}_{1}$ - Control & 20.20 & 2956.00 & 5142.00 \\
\hline $\mathrm{T}_{2}-0.5 \% \mathrm{KCl}$ & 21.65 & 3080.00 & 5335.00 \\
\hline $\mathrm{T}_{3}-1.0 \% \mathrm{KCl}$ & 21.18 & 3300.00 & 5238.00 \\
\hline $\mathrm{T}_{4}-1.0 \% \mathrm{MgSO}_{4}$ & 21.33 & 3415.00 & 5385.00 \\
\hline $\mathrm{T}_{5}-2.0 \% \mathrm{MgSO}_{4}$ & 21.63 & 3225.00 & 5375.00 \\
\hline$T_{6}-0.3 \%$ Boricacid & 21.58 & 3250.00 & 5486.00 \\
\hline $\mathrm{T}_{7}-\mathbf{0 . 6} \%$ Boricacid & 21.60 & 3210.00 & 5400.00 \\
\hline$T_{8}-0.25 \%$ Salicylic acid & 21.73 & 3315.00 & 5408.00 \\
\hline$T_{9}-0.5 \%$ Salicylic acid & 22.03 & 3280.00 & 5351.00 \\
\hline SEm \pm & 0.52 & 38.08 & 0.78 \\
\hline CD at $5 \%$ & NS & 118.45 & NS \\
\hline
\end{tabular}

Data regarding grain and straw yield per hectare as well as 1000 grain weight are presented (Table 2). The perusal of data reveals that all the treatments registered significant increase in grain yield per hectare. However, maximum increase in grain yield was recorded with $1 \% \mathrm{MgSO}_{4}(3415.00 \mathrm{~kg}$ $\left.\mathrm{ha}^{-1}\right)$ and minimum with $0.5 \% \mathrm{KCl}(3080.00$ $\left.\mathrm{kg} \mathrm{ha}{ }^{-1}\right)$. While in case of straw yield per hectare and 1000 grain weight, the spraying of chemicals did not produce significant effect. The results are in accordance with the findings of Raza et al., (2014) who reported that foliar application of B significantly affected on grain yield, number of grains spike $^{-1}$ and 1000 grains weight. Similar results were also reported by Moghadam et al., (2011) that the foliar application of B and $\mathrm{Zn}$ had positive effect on yield and yield components of wheat. The enhanced wheat 
crop yield by B spraying at booting stage may be due to provision of $\mathrm{B}$ at initial stages which might have enhanced the accumulation of assimilate in the grains (Arif et al., 2006). The higher crop yield under B application is the result of positive role of $B$ in pollen grain formation, pollen tube formation, grain set, pollination, flower set and pollen grains viability at booting stage (Subedi et al., 1997a).

In conclusion, the results of this experiment shows that spraying of 0.5 and $1.0 \% \mathrm{KCl}, 1.0$ and $2.0 \% \mathrm{MgSO}_{4}, 0.3$ and $0.6 \%$ Boric acid, 0.25 and $0.5 \%$ salicylic acid significantly increased Yield and yield attributes viz., panicle bearing tillers plant $^{-1}$, number of grains panicle ${ }^{-1}$, number of fertile grains panicle $^{-1}$, grain yield $\left(\mathrm{kg} \mathrm{ha}^{-1}\right)$ and straw yield $\left(\mathrm{kg} \mathrm{ha}^{-1}\right)$. There was non-significant effect of treatments on 1000 grains weight as compare to control.

This study show the importance of micronutrients and plant growth regulator on plants that improves yield and yield components viz., number of panicles bearing tillers plant $^{-1}$, number of grains panicle ${ }^{-1}$, number of fertile grains panicle ${ }^{-1}$, grain yield $\left(\mathrm{kg} \mathrm{ha}^{-1}\right)$, straw yield $\left(\mathrm{kg} \mathrm{ha}^{-1}\right)$ and 1000 grains weight. All the treatments reduced the number of sterile grains which helped in obtaining higher yield.

\section{References}

Abd El-Hadi, A. H., Ismail, K. M. and ElAkahawy, M. A. (1997). Effect of potassium on the drought resistance of crops in Egyptian conditions, In Johnston, AE.: Food Security in the WANA Region, the Essential Need for Balanced Fertilization. Int. Potash Inst Basel: 328-336.

Akhgary, H. (2004). Rice (Agriculture, regrowth, nutrition). Rasht Islamic
Azad University's publication. 481 , in persion.

Arif, M., Chohan, M. A., Ali, S., Gul, R. and Khan, S. (2006). Response of wheat to foliar application of nutrients. $J$. Agric. Soc. Sci., 1 (4): 30-34.

Aslam, M., Mahmood, I. H., Qureshi, R. H., Nawaz, S. and Akhtar, J. (2002). Salinity tolerance of rice as affected by boron nutrition. Pak. J. Soil Sci., 21: 110-118.

Bajaj, S. and Mohanty, A. (2005). Recent advances in rice biotechnology towards genetically superior transgenic rice. Plant Biotechnology J., 3: 275-307.

Bernier, J., Atlin, G. N., Serraj, R., Kumar, A., and Spaner, D. (2008). Breeding upland rice for drought resistance. $J$. Sci. Food Agric., 88: 927-39.

Goldbach, H. E. and Wimmer, M. (2007) Boron in plants and animals: Is there a role beyond cell-wall structure? Journal Plant Nutr. Soil Sci., 170: 3948.

Harkamal, W., Clyde, W., Linghe, Z., Abdelbagi, M. I., Pascal, C. and Timothy, J. C. (2007). Genome wide transcriptional analysis of salinity stressed japonica and indica rice genotypes during panicle initiation stage. Plant Mol. Biol., 63: 609-623.

Hayat, S. and Ahmad, A. (2007). Salicylic Acid - A Plant Hormone. Dordrecht: Springer.

Horváth, E., Szalai, G. and Janda, T. (2007) Induction of abiotic stress tolerance by salicylic acid signaling. $J$ Plant Growth Regul., 26: 290-300 2007.

Hussain, M., Malik, M. A., Farooq, M., Ashraf, M. Y. and Cheema, M.A. (2008). Improving drought tolerance by exogenous application of glycinebetaine and salicylic acid in sunflower. Journal of Agronomy and Crop Science, 194, 193-199. 
Kamoshita, A., Babu, R. C., Boopathi, N. M. and Fukai, S. (2008). Phenotypic and genotypic analysis of droughtresistance traits for development of rice cultivars adapted to rain fed environments. Field Crops Res., 109: $1-23$.

Larkindale, J., and Huang, B. (2004). Thermo-tolerance and antioxidant systems in Agrostisstolonifera: Involvement of salicylic acid, abscisic acid, calcium, hydrogen peroxide and ethylene. Journal of Plant Physiology, 161: 405-413.

Masoud, B., Rooholla, A., Ghasem, M. N., Khatoon, Y. and Sayed, M. T. (2012). Effect of different microelement treatment on wheat (Triticum aestivum L.) growth and yield. International Research Journal of Applied Basic Science, 3 (1): 219-223.

Moghaddam, N. M., Arvin, M. J., Nezhad, G. R. K. and Maghsoudi, K. (2011). Effect of salicylic acid on growth and forage and grain yield of maize under drought stress in field conditions. [Persian]. Seed and Plant Production Journal, 27-2 (1): 41-55.

Nadim, M. A., Awan, I. U., Baloch, M. S., Khan, E. A., Naveed, K. and Khan, M. A. (2012).Response of wheat (Triticum aestivum L.) to different micronutrients and their application methods. J. Anim. Plant Sci., 22(1): 113-119.

NaliniPandey and Bhavana Gupta (2013). The impact of foliar boron sprays on reproductive biology and seed quality of black gram. Journal of Trace Elements in Medicine and Biology, 27: 58-64.

Parinazkohnaward, Jalal Jalilian and Alireza Pirza (2012). Effect of foliar application of micro-nutrients on yield and yield components of safflower under conventional and ecological cropping systems. International Research Journal of Applied Basic Science, 3 (7): 1460- 1469.

Patel, T., Nayak, T. and Mishra, V. N. (2016). Effect of different fertility levels and nutrient uptake by drought tolerant rice genotypes under rainfed condition. The Bioscan, 11(1):401406.

Rao, M. V., Paliyath, G., Ormrod, P., Murr, D. P. and Watkins, C. B. (1997). Influence of salicylic acid on $\mathrm{H}_{2} \mathrm{O}_{2}$ production, oxidative stress, and $\mathrm{H}_{2} \mathrm{O}_{2}$ metabolizing enzymes. Plant Physiology, 115: 137-149.

Raza, S. A., Ali, S., Chahill, Z. S. and Iqbal, R. M. (2014).Response of foliar application of boron on wheat (Triticum aestivum L) crop in calcareous soils of Pakistan. Acad. J. Agric. Res., 2 (3): 106-109.

Rehman, A., Farooq, M., Cheema, Z. A. and Wahid, A. (2012). Seed priming with boron improves growth and yield of fine grain aromatic rice. Plant Growth Regul, doi: 10.1007/s10725-012-97062.

Saeed, B., Gul, H., Khan, A. Z., Badshah, N. L., Parveen, L. and Khan A (2012). Rates and methods of nitrogen and sulfur application influence and cost benefit analysis of wheat. Journal of Agricultural \& Biological Science, 7(2): 81-85.

Saleem, M., Khanif, Y. M., Ishak, F., Samsuri, A. W. and Hafeez, B. (2011) Importance of Boron for Agriculture Productivity: A Review. Int Res. J. Agric. Sci. Soil Sci. 1(8): 293-300.

Subedi, K. D., Budhathoki, C. B. and Subedi, M. (1997a). Variation in sterility among wheat (Triticum aestivum L.) cultivars in response to boron deficiency in Nepal. Euphytica, 95: 21-26.

Torun, A., ltekin, I. G. A., Kalayci, M., 
Yilmaz, A., Eker, S. and Cakmak, I. (2001). Effects of zinc fertilization on grain yield and shoot concentrations of zinc, boron, and phosphorus of 25 wheat cultivars grown on a zinc deficient and boron-toxic soil. Journal of Plant Nutrition, 24 (11): 18171829.

Verma, V. K., Meena, R. N., Gautam, A., Gaurav, Tyagi, V. and Kumar, A. (2015). Effect of crop establishment method and different source of $\mathrm{zn}$ on growth, yield and quality of rice (Oryza sativa L.). The Ecoscan. 9(3 \& 4): 873-876.

Waraich, E. A., Amad, R., Ashraf, M. Y., Saifullah and Ahmad, M. (2011). Improving agricultural water use efficiency by nutrient management. ActaAgriScandi-Soil \& Plant Sci., 61 (4): 291-304.

\section{How to cite this article:}

Vikas Yadav, MayankPratap, A.H. Khan, R.K. Yadav and Rajneesh. 2019. Foliar Response of Chemicals on yield and yield Attributing Characters of Rice (Oryza sativa L.) under Rain Fed Condition. Int.J.Curr.Microbiol.App.Sci. 8(02): 2756-2762.

doi: https://doi.org/10.20546/ijcmas.2019.802.323 